\title{
ENHANCING MANAGEMENT MEASURES ON STUDENTS' SELF- STUDY ACTIVITIES AT THAI NGUYEN UNIVERSITY OF SCIENCES
}

\author{
Phi Dinh Khuong*, Lam Thuy Duong \\ $T N U$ - University of Sciences
}

\begin{abstract}
This study indentified the performance of the self-study activities of students in terms of: students' awareness on self-study, study skills, services for self-study, teaching method and administration. Specially, it aimed to find out the factors both externally and internally that may affect the activities of students' self-study; to find out the relationship between self-study activities and factors affecting the self-study activities; to identify the different management measures of self-study activities; to assess the necessity and feasibility of the management measures for self-study activities; to develop a management measures for students self-study activities based from its necessity and feasibility. It is designed to help determine the extent to which different variables are related to each other in the population of interest. The study would provide leaders with a clear idea on how effective and successful they should have in the work as management of self-study in university.

Keywords: Self-study activities; management of self- study; management measures of self-study activities; characteristics of students' self-study activities; the nature of management of self-study activities.
\end{abstract}

\section{NÂNG CAO BIỆN PHÁP QUẢN LÝ HOẠT ĐỘNG TỬ HỌC CỦA SINH VIÊN TRƯỜnG ĐẠI HỌC KHOA HỌC - ĐẠ̇I HỌC THÁI NGUYÊN}

Phí Đình Khương*, Lâm Thùy Dương Truờng Đại học Khoa học - ĐH Thái Nguyên

\section{TÓM TẮT}

Nghiên cứu đã xác định được thực trạng của hoạt động tự học của sinh viên về các phương diện: nhận thức, kỹ năng, các điều kiện phục vụ cho tự học, phương pháp giảng dạy, công tác quản lý. Xác định các yếu tố ảnh hưởng đến hoạt động tự học bao gồm cả yếu tố khách quan và yếu tố chủ quan. Tìm ra mối quan hệ giữa hoạt động tự học và yếu tố ảnh hưởng đến hoạt động tự học, đề xuất các biện pháp quản lý hoạt động tự học.Tác giả đã sử dụng phương pháp mô tả, phân tích để tìm ra được sự liên quan đến nhận thức giữa các nhóm đối tượng, đồng thời tìm ra những yếu tố có ảnh hưởng đến hoạt động tự học của sinh viên. Nghiên cứu sẽ cung cấp cho các nhà lãnh đạo một ý tưởng rõ ràng về hiệu quả và thành công của các hiệu trưởng trong công việc quản lý hoạt động tự học của sinh viên trong trường đại học.

Từ khóa: Hoạt động tụ học; quản lý hoạt động tụ học; biện pháp quản lý hoạt động tụ học; đặc điểm của hoạt động tư học của sinh viên; bản chất của quản lý hoạt động tụ học.

Ngày nhận bài: 22/8/2019; Ngày hoàn thiện: 23/9/2019; Ngày đăng: 30/9/2019

\footnotetext{
* Corresponding author. Email: khuongpd@tnus.edu.vn
} DOI: https://doi.org/10.34238/tnu-jst.2020.03.1984 


\section{Introduction}

For the level of higher education, the requirements on methods in Article 40 of the Vietnamese Law on Education (2005) states: "Methods of college and university education must pay attention to the advancement of the self-consciousness in study, of ability of selfstudy, self-taught, developing creative thinking, drilling of practical skills, facilitate students in participating in research, experimentation and application"[1].Thai Nguyên University of Sciences (TNUS) was established on 24 October 2002 on the foundation of Faculty of Natural and Social Sciences-Thai Nguyen University. TNUS has total staff of over 300 in which, there are 8 associate professors, 90 doctors, 138 masters and 66 teachers are taking $\mathrm{PhD}$ coures. The number of students in 2018- 2019 is 4000 . Its goal is to become a university which educates and trains students in multi disciplines and branches, and serves as a research centre of science and technology, meeting the need of economic, cultural and social development in Thai Nguyen province and her neighbors. However with the increasing requirements on the qualification of human resources, the schools should have the synchronizationed solutions to improve the quality of training. These solutions must be oriented to studentsthe subject of the training process. From the above problems, the identification of measures to organize, manage study activities of students of TNUS in order to improve the quality of school education is a critical issue.

\section{Literature review}

Entering the twenty-first century, human beings have encountered drastic changes of modern civilization as the result of the achievements of science and technology created breakthroughs in all areas of social life [2], [3]. Education is considered a key factor for the development of the society as required by that trend. With the development of science and technology, the amount of human knowledge has been increased every second while time for learning in the school is limited. Therefore, being equipped with selfstudy method to acquire the knowledge is an inevitable trend [4], [5].

Many authors mentioned and approached selfstudy, our perspective self-study is a form of cognitive activity of individuals [6]. It is a voluntary and positive activity, self-promote their own internal resources to acquire knowledge, skills and techniques [7], [8]. Selfstudy is a way of dy in which people study with self-awareness, positively, proactively, independently to capture knowledge in a certain area of life in order to achieve their goals [9].

Over the past years, TNUS has made great efforts in training human resources for Thai Nguyen province and the region, due to the increasing requirements on the qualification of human resources, the university should have the synchronization solutions to improve the quality of training. These solutions must be oriented to students - the subject of the training process [10], [11]. In fact, most of the fresh students do not have the habit of active and positive study, self-study skills but their study mainly relies on the knowledge imparted by college instructors [12,[13]. In addition, factors such as physical facilities, textbooks and curricula for teaching and learning have many shortcomings affect the quality of school education [14], [15]. With the above reasons, author chose the topic: "Enhancing the management measures of students' self-study activities at Thai Nguyen University of Sciences" to propose management measures with the aim of improving the university's quality of education.

\section{Methodology}

\section{Scope and Limitation of the Study}

This study was conducted at TNUS. The respondents were composed of 148 administrators and 308 students from the different faculties and departments of TNUS. 


\section{Population and Sampling}

148 of teaching staff $(65 \%)$ of nine functional departments and training divisions and 308 of students $(10 \%)$ of eight faculties of the university were requested to answer the questionnaires.

\section{Instrumentation}

The author designed a questionnaire, which is a main tool in gathering data. The questionnaires are divided into parts namely: survey questionnaire on the status, the survey on the necessity and feasibility of the measures.

\section{Data Gathering Procedure}

The researcher asked permission from different heads of TNUS to conduct his study. Upon approval, he administered the questionnaire to his respondents. $\mathrm{He}$ explained clearly the purpose of the study and after answering the instrument, he retrieved them on the same day. The data were tallied, tabulated and analyzed afterwards.

\section{Statistical Treatment}

- Weighted mean was utilized to describe the perception of the status of self-study activities, the factors that may affect the students' self-study activities, the management measures.

- Chi-square test, for determining the significant relationship of the self-study activities and the factors that may affect the students' self-study activities.

- To see the correlation between the necessity and feasibility of the self-study activities management measures as mentioned, we use the formula coefficients' hierarchy Specimen to calculate.

\section{Results and discussions}

\subsection{Results}

This study will be beneficial to objects listed as follows:

Students: They will be benefited by this study because they are the main concern of training process. From the results of the study, students can recognize both strengths and weaknesses of situation on students' self-study activities in so that each student should clearly dentify their motivation, attitude and self-study methods to achieve high academic results.

Lecturers: The outcome of the study is of great help to lectures have more awareness of the factors affecting the activities of students' self-study. Since then, each lecturer will take measures to raise awareness and self-study skills for students, making them more active and proactive in self-study activities. Also, this study will help them identify measure to improve the efficiency of selflearning activities for students to contribute to improving the quality of school education

Administrators: It is hoped that the study will help the administrators to see the status of self-study activities, the management of selfstudy activities of the school, and provide them with the management measures used for reference in managing selfstudy activities of students in the university.

\subsection{Discussions}

\section{Status of the self-study activities}

Table 1. Frequency and Weighted Mean Distribution on the status of students' self-study sctivities as to its awareness on self-study

\begin{tabular}{lcccccc}
\hline \multicolumn{1}{c}{ Statement } & VMA & A & NA & SNA & WM & QD \\
\cline { 2 - 7 } & $\mathbf{4}$ & $\mathbf{3}$ & $\mathbf{2}$ & $\mathbf{1}$ & & \\
\hline I am aware of the; & & & & & & \\
Activities of the self-study program. & 73 & 244 & 11 & 3 & 3.17 & $\mathrm{~A}$ \\
Goals/objectives of the self-study program. & 64 & 251 & 10 & 1 & 3.16 & $\mathrm{~A}$ \\
University program on self-study. & 66 & 253 & 11 & 0 & 3.16 & $\mathrm{~A}$ \\
Procedure on how to conduct the self-study activities. & 48 & 235 & 37 & 5 & 3.0 & $\mathrm{~A}$ \\
Benefits of the self-study activities. & 131 & 185 & 12 & 2 & 3.36 & $\mathrm{~A}$ \\
$\quad$ Average weighted mean & & & & & $\mathbf{3 . 1 7}$ & A \\
\hline
\end{tabular}


Table 1 points out the result of self-study cognition activities on 5 contents, weighted average result is 3.17 , meaning that students all are aware of the importance of the self-study. Criterion number 5 is 3.36 points, revealing that students are aware of the benefits of the self-study at the highest level.

Table 2. Frequency and Weighted Mean Distribution on the status of students' self-study activities as to its study skills

\begin{tabular}{lcccccc}
\hline \multicolumn{1}{c}{ Statement } & SA & A & D & SD & WD & QD \\
\cline { 2 - 7 } & $\mathbf{4}$ & $\mathbf{3}$ & $\mathbf{2}$ & $\mathbf{1}$ & & \\
\hline The Self-study activities help me to: & & & & & & \\
Enhance my critical thinking skills. & 141 & 177 & 9 & 1 & 3.39 & SA \\
Enhance my comprehension skills. & 143 & 174 & 11 & 0 & 3.40 & SA \\
Develop my reading skills. & 128 & 180 & 14 & 6 & 3.32 & SA \\
Develop my note taking skills. & 132 & 176 & 18 & 2 & 3.34 & SA \\
Develop my time management skills & 120 & 192 & 12 & 4 & 3.30 & SA \\
Enhance my problem solving skills. & 116 & 182 & 26 & 4 & 3.25 & SA \\
Average Weighted Mean & & & & & $\mathbf{3 . 3 3}$ & SA \\
\hline
\end{tabular}

Table 2 shows the evaluation results of the self-study impact on improving learning skills. The weighted average result is 3.33 , the skill that is assessed to be at highest point level is the $2^{\text {nd }}$ skill - comprehension skills with the 3.4 weighted average points; the skill assessed to be the lowest point is the recording skill.

Table 3. Frequency and Weighted Mean Distribution on the status of students' self-study activities as to students' habits during self-study

\begin{tabular}{|c|c|c|c|c|c|c|}
\hline \multirow{2}{*}{ Statement } & $\mathbf{O}$ & $\mathbf{S}$ & $\mathbf{R}$ & $\mathbf{N}$ & WD & QD \\
\hline & 4 & 3 & 2 & 1 & & \\
\hline $\begin{array}{l}\text { I browse the headings, pictures, chapter questions and summaries } \\
\text { before I start reading a chapter. }\end{array}$ & 153 & 149 & 25 & 1 & 3.39 & $\mathrm{O}$ \\
\hline When I self-study, I do first the difficult subject. & 126 & 155 & 41 & 6 & 3.23 & $\mathrm{~S}$ \\
\hline I try to get the meaning of new words as I see them for the first time. & 118 & 147 & 56 & 7 & 3.15 & $\mathrm{~S}$ \\
\hline I review my class notes after class. & 107 & 152 & 56 & 13 & 3.07 & $\mathrm{~S}$ \\
\hline I take notes as I read my text books/reading materials. & 90 & 136 & 73 & 29 & 2.82 & $\mathrm{R}$ \\
\hline $\begin{array}{l}\text { I study for a length of time then take a short break before returning } \\
\text { to studying. }\end{array}$ & 123 & 145 & 49 & 11 & 3.16 & $\mathrm{~S}$ \\
\hline $\begin{array}{l}\text { I have all my supplies handy when I study, such as pens, paper, } \\
\text { calculator, etc. }\end{array}$ & 196 & 95 & 32 & 5 & 3.47 & $\mathrm{O}$ \\
\hline Average Weighted Mean & & & & & 3.18 & $\mathbf{S}$ \\
\hline
\end{tabular}

Table 3 shows assessment result on 07 habits in the self-study, the result of these seven contents is 3.18 point, which is at credit level; the highest score is of the $7^{\text {th }}$ content with 3.47 point, ie that the students have habits to prepare well the learning tools. The most popular habit in the selfstudy is to review the class notes.

Table 4. Frequency and Weighted Mean Distribution on the status

of students' self-study activities as to Services for self-study support

\begin{tabular}{lcccccc}
\hline \multicolumn{1}{c}{ Statement } & SA & A & D & SD & WD & QD \\
\cline { 2 - 7 } & $\mathbf{4}$ & $\mathbf{3}$ & $\mathbf{2}$ & $\mathbf{1}$ & & \\
\hline There is an available place to conduct self-study around the school campus. & 150 & 132 & 36 & 10 & 3.29 & SA \\
Books and other reading materials are available to use for self-study. & 132 & 157 & 35 & 4 & 3.27 & SA \\
Wi-fi /Internet access is provided for self- study. & 148 & 143 & 30 & 7 & 3.32 & SA \\
The library is always available for self- study & 155 & 149 & 18 & 6 & 3.38 & SA \\
Vacant classrooms are allowed to be used for self-study. & 128 & 151 & 42 & 7 & 3.22 & A \\
Resources like radio, television and other electronic media are available & 112 & 166 & 45 & 5 & 3.17 & A \\
for self-study. & & & & $\mathbf{3 . 2 8}$ & SA \\
Average Weighted Mean & & & & &
\end{tabular}


Table 4 shows the survey of services for the self-study support with six contents, with the result of 3.28 point, ie basically, service conditions for the self-study have met the needs of students. Accordingly, the library service is assessed to be at the highest level of 3.38, the media is at the lowest level with 3.17. This reflects correctly the reality of the university currently.

Table 5. Frequency and Weighted Mean Distribution on the status of students' self-study activities as to Teacher initiative

\begin{tabular}{lcccccc}
\hline \multicolumn{1}{c}{ Statement } & SA & A & D & SD & WD & QD \\
\cline { 2 - 7 } & $\mathbf{4}$ & $\mathbf{3}$ & $\mathbf{2}$ & $\mathbf{1}$ & & \\
\hline $\begin{array}{l}\text { Teacher plans specific activities outside class hours and self-study } \\
\text { activities of students. }\end{array}$ & 147 & 159 & 20 & 2 & 3.38 & SA \\
Teachers give tasks to do at home. & 120 & 195 & 12 & 1 & 3.32 & SA \\
Teachers require students to engage in self-study activities daily. & 110 & 188 & 30 & 0 & 3.24 & A \\
Teachers ask students to read books and references before and after class. & 146 & 159 & 21 & 2 & 3.37 & SA \\
Teaching method use promotes the self- study activities & 125 & 178 & 24 & 1 & 3.30 & SA \\
Methods of testing and assessment require students to do self-study. & 113 & 181 & 32 & 2 & 3.23 & A \\
Average Weighted Mean & & & & & $\mathbf{3 . 3 1}$ & SA \\
\hline
\end{tabular}

Table 5 shows the assessment of the teacher initiative with seven contents. Average result is 3.31, ie the contents are highly appreciated and activities of teachers have great effect on the self-study of students.

Table 6. Frequency and Weighted Mean Distribution on the status of students' self-study activities as to self-study location

\begin{tabular}{lcccccc}
\hline \multicolumn{1}{c}{ Statement } & $\mathbf{O}$ & $\mathbf{S}$ & $\mathbf{R}$ & $\mathbf{N}$ & WD & QD \\
\cline { 2 - 7 } & $\mathbf{4}$ & $\mathbf{3}$ & $\mathbf{2}$ & $\mathbf{1}$ & & \\
\hline I usually do my self-study at...... & 234 & 70 & 19 & 5 & 3.63 & $\mathrm{O}$ \\
Home & 59 & 74 & 55 & 140 & 2.16 & $\mathrm{~S}$ \\
Friends house & 156 & 118 & 46 & 6 & 3.30 & $\mathrm{O}$ \\
Dorm & 32 & 166 & 105 & 27 & 2.62 & $\mathrm{~S}$ \\
Quiet place & 64 & 180 & 57 & 27 & 2.86 & $\mathrm{~S}$ \\
Any vacant space around the campus & 58 & 115 & 88 & 67 & 2.49 & $\mathrm{R}$ \\
Vacant classroom & 50 & 100 & 87 & 91 & 2.33 & $\mathrm{~S}$ \\
Library & & & & & $\mathbf{2 . 7 7}$ & $\mathbf{S}$ \\
Average Weighted Mean & & & & & & \\
\hline
\end{tabular}

The survey result shows that learning at home is the most popular choice with 3.63 average points, next is the self-study at silent places with 3.30 points. General result is 2.77 points, meaning that students do not choose any fixed place.

Table 7. Frequency and Weighted Mean Distribution on the status of students' self-study activities as to administration

\begin{tabular}{lcccccc}
\hline \multicolumn{1}{c}{ Statement } & ACO & CO & UNO NCO WD QD \\
\cline { 2 - 6 } & $\mathbf{4}$ & $\mathbf{3}$ & $\mathbf{2}$ & $\mathbf{1}$ & \\
\hline Manages faculty's teaching activities to influence student self-learning. & 125 & 154 & 35 & 13 & 3.20 CO \\
Motivates students to engage in self-study activities to enhance learning. & 70 & 186 & 69 & 3 & 2.99 CO \\
$\begin{array}{l}\text { Supervise monitoring and assessment of students' learning outcomes } \\
\text { based from self- study activities. }\end{array}$ & 50 & 176 & 89 & 12 & 2.80 CO \\
Manages self-study activities outside of class hours. & 92 & 173 & 47 & 16 & 3.05 CO \\
Manages the implementation of students ${ }^{e e}$ self-study activities. & 105 & 187 & 33 & 2 & 3.2 & CO \\
Coordinates departments and organizations in the implementation of & 65 & 177 & 67 & 19 & 2.89 CO \\
students' self-study activities.. & & & & & $\mathbf{3 . 0 2}$ CO \\
Average Weighted Mean & & & & &
\end{tabular}


Table 7 shows the evaluation of the university management on the self-study activities with six contents, the average result of management content is 3.02 points, ie these contents are frequently carried out. The $1^{\text {st }}$ content gets the highest score with 3.2 points; it is the management on teaching activities of teachers to positively affect on the self-study of students. The lowest score is of management on the self-study activities outside of class time with 2.8 points. This fact is consistent with the actual situation of the university.

\section{Survey results}

Measure 1: Planning management of the selfstudy, necessity to evaluate average point $\mathrm{X}=$ 2.95 , ranking $5^{\text {th }}$ order; feasibility $X=2.87$ ranks $5^{\text {th }}$ order.

Measure 2: Organizing activities to raise awareness, building attitude and self-study skills training for students, necessity to evaluate average point $X=2.98$ ranking $1^{\text {st }}$ order; feasibility $\mathrm{X}=2.96$ ranking $2^{\text {nd }}$ order.

Measure 3: Implement renovation of teaching method in order to develop the self-study activeness, necessity of evaluation $\mathrm{X}=2.97$ average point ranking $2^{\text {nd }}$ order; feasibility $\mathrm{X}=2.96$ ranking $2^{\text {nd }}$ order.

Measure 4: Strengthening scientific research activities to promote the self-study motivation, necessity of evaluation with average point of $X=2.97$ ranking $2^{\text {nd }}$ order; feasibility $X=2.97$ ranking $1^{\text {st }}$ order.

Measure 5: Organizing and managing extra curriculum activities of students, necessity of evaluation $X=2.97$ average point ranking $2^{\text {nd }}$ order; feasibility $\mathrm{X}=2.91$ ranking $3^{\text {rd }}$ order.

Measure 6: Manage and use efficiently facilities for the self-study activities, necessity of evaluation $X=2.97$ average point ranking $2^{\text {nd }}$ order; feasibility $\mathrm{X}=2.88$ ranking $4^{\text {th }}$ order.

In terms of necessity, ranking $1^{\text {st }}$ order is the $1^{\text {st }}$ measure with $\mathrm{X}=2.98$ average point; The measure of activity organization to enhance awareness, to construct motivation, attitude and self-study skill for students is one, which directly affects on students.

In terms of feasibility, ranking $1^{\text {st }}$ order is the $4^{\text {th }}$ measure with $X=2.97$ average point; the measure of scientific research activity increase to develop self-study motivation is a good method to arouse the independence, creativeness of learners.

In order to see correlation between the necessity and the feasibility of the management measures of the students' selfstudy activities, the author uses the ranking correlation coefficient formula of Specimen: $\mathrm{R}=0.88$ showed the following:

- The relationship between the necessity and feasibility of the management measures are positively correlated because $\mathrm{R}=0.88$ marked $(+)$, which is closely correlated, ie the necessity and feasibility of the management measures are highly relevant.

- The necessity of measures is at which extent, the feasibilities will be at the respective level. From the test results, teachers and managers interviewed appreciated the necessity and feasibility of the measures proposed by the author. This shows that the proposed measures in the thesis is the basis for the practical application of the selfstudy management of students' TNUS.

\section{Conclusions and recommendation}

\subsection{Conclusions}

Based on the findings, the reseacher came up with the following conclusions:

1. For students' level of awareness on the selfstudy activities with an average weighted mean of 3.17 following Likert. Students' awareness on self- study: Students are obtaining better outcomes for the improvement of their academics as resulted from the instituition's program on self- study

2. For students' self- study skills with an average weighted mean of 3.33. Study skills: Students have good understanding of the importance of study skills for their enhancement in acadamic performances. 
3. For students' habits during self-study with an average weighted mean of 3.18. Habits during self-study basically meet the requirement of self-study. They spend time to review the class notes after class and prepare all the supplies handy when studying. The habits during self-study that require the initiative and creativity in self-study of students is not high. They mainly focuss on the content following the guidance of teacher.

4. Services for self-study support with an average weighted mean of 3.28. Services for self-study generally provide the the basical need of students for their study but the study resources are not highly appreciated.

5. Teaching method with an average weighted mean of 3.31. Self-study location is the atracted issue to student. In general, students are facing with difficulties in finding a place to study. Students often choose to study at home and a quiet place

6. Self-study location with an average weighted mean of 2.77 . Teaching initiative is considered the decisive factor to the selfstudy method of students.

7. Administration with an average weighted mean of 3.02. Administration level reflects that the school have been applying the certain measures for self-study management.

\subsection{Recomendation}

Based on the findings of the study, the following are recommended:

- The director board should pay more attention to policies, direction in management of students' self-study activities. Concretize them in written documents; the guiding ideology of the school to the relevant department implemented a basis.

- Enhanced direct the innovation of teaching methods, assessment of teachers towards promoting positivity of the school; organizing regularly practical activities, forging skills for students.
- Give more investment on facilities catering for teaching and learning in a systematic and modern standard. Effective exploitation of the Center for Information and electronic library to provide full and timely documentation of teaching and in service learning.

- Enhance training methods and student study skills, self-study, arouse desire in student learning, making students more interested in learning.

- Organize multiple playgrounds, useful forum for students, such as students studying science club courses, conferences and seminars on self-learning method for students; Stock powerful movement for autonomy in learning; movement launched initiatives proposed in academic and creative ideas.

- The director board should pay more attention to organize activities for students practical approach, promoting the spirit of volunteerism for community life, such as voluntary youth movement; application of scientific advances to life, linking theory with practice through which students are constantly learning and trying in practice, there is more a sense of responsibility for themselves, their community and society.

\section{REFERENCES}

[1]. Education Law. National Political Publishing House, Hanoi, 2005.

[2]. H. C. Nguyen, Vietnam Education early years of the twenty-first century. Education Publishing House, 2007.

[3]. Forecast for the twenty-first century. Statistical Publishing House, 1998.

[4]. Q. B. Dang, A new approach to scientific management and the application in educational management, 1995.

[5]. C. D. Vu, Curriculm research methodology. Education Publishing House, 2007.

[6]. F. E. Weinert, The development of cognitive learning and teaching. Education Publishing House, 1998.

[7]. T. N. Pham, Management of quality in higher education. National University Publishing House, Hanoi, 2000. 
[8]. C. T. Nguyen, The process of self-study training, study and train how to study, 2004.

[9]. C. T. Nguyen, Collection of works of selflearning and self-education self-study. Educational publishing house, 2001.

[10]. Ministry of Education \& Training, Regulation of higher education and college system of government under the credit system, 2007.

[11]. V. D. Nguyen, Self- study is the experience of a lifetime of every human being, selflearning and self-training - the strategic thinking of Vietnamese educational development. Education Publishing House, Hanoi, 1998.

[12]. K. D. Tran, Management and quality control of personnel training. Education Publishing House, 2004.

[13]. P. Exipov, The theoretical basis of teaching. Educational Publishing House, Hanoi, 1997.

[14]. K. C. Pham, Commenxiki-father of modern pedagogy. Education Publishing House, 1997.

[15]. D. C. Nguyen, Quality Management trainingthematic project for junior teachers, 2004. 